\title{
Hubungan Antara Kontrol Diri Dan Stres Kerja Dengan Perilaku Cyberloafing Pada Pegawai Negeri Sipil (PNS) Di Kantor Pelayanan Bea Dan Cukai Kota Pekanbaru
}

\author{
Widiya Adhana ${ }^{1}$, Jhon Herwanto ${ }^{2}$ \\ ${ }^{1,2}$ Fakultas Psikologi Universitas Islam Negeri Sultan Syarif Kasim Riau \\ john.herwanto@uin-suska.ac.id
}

\begin{abstract}
Abstrak
Perilaku cyberloafing adalah perilaku pegawai yang menggunakan akses internet dengan jenis komputer (seperti deskop, cell-phone, tablet) saat bekerja untuk aktivitas yang tidak berhubungan dengan pekerjaan seperti hiburan belanja online, internet messaging serta menonton film sehingga dapat mengganggu aktivitas pekerjaan pegawai. Beberapa faktor yang dapat mempengaruhi perilaku cyberloafing adalah kontrol diri dan stres kerja. Penelitian ini bertujuan untuk melihat hubungan kontrol diri dan stres kerja terhadap perilaku cyberloafing. Desain penelitian menggunakan kuantitatif korelasional, dengan subjek pegawai negeri sipil (PNS) di kantor Pelayanan Bea dan Cukai Pekanbaru sebanyak 83 orang. Alat ukur penelitian menggunakan skala perilaku cyberloafing, skala kontrol diri, dan skala stres kerja. Teknik analisis data menggunakan analisis regresi berganda, diperolah hasil sig. 0,000 (p<0,01) dan nilai koefisien korelasi sebesar 0,620, dengan sumbangan efektif sebesar 38,4\%. Artinya terdapat hubungan antara kontrol diri dan stres kerja dengan perilaku cyberloafing. Dengan demikian, kontrol diri dan stres kerja berpengaruh terhadap perilaku cyberloafing pada pegawai negeri sipil (PNS) di Kantor Pelayanan Bea dan Cukai Pekanbaru.
\end{abstract}

Kata kunci: perilaku cyberloafing, kontrol diri, dan stres kerja.

\begin{abstract}
Cyberloafing behaviour is the behaviour of employees who use internet access with a type of computer (such as desk, cell-phone, tablet) when working for activities that are not related to work such as online shopping entertainment, internet messaging and watching movies so that it can interfere with employee work activities. The factors that influence cyberloafing behaviour are self control and job stress. This study aims to look at the relationship between self control and work stress on cyberloafing behavior. This study uses a correlational quantitative design, with 83 civil servants subjects in the Pekanbaru Customs and Excise Service office. The research measuring instrument are cyberloafing behaviour, self-control scale, and job stress scale. Data analysis technique used is multiple regression analysis, obtained sig results. 0,000 $(p<0.01)$ and the correlation coefficient of 0.620 , with an effective contribution of $38.4 \%$. This means that there is a relationship between self-control and job stress with cyberloafing behaviour. Thus, self-control and work stress affect the behavior of cyberloafing in civil servants (PNS) in Pekanbaru Customs and Excise Service office.
\end{abstract}

Keywords: cyberloafing behaviour, self control, and job stress. 


\section{Pendahuluan}

Penerapan teknologi internet telah dilakukan oleh semua instansi di kota Pekanbaru dan sekitarnya, bahkan instansi memfasilitasi tiap pekerjannya dengan satu komputer perorang. Keberadaan fasilitas komputer dan internet diharapkan membantu pegawai negeri sipil dalam menyelesaikan tugasnya dengan cepat dan efesien, meningkatkan kreatifitas pegawai, membantu karakter pelayanan kepada masyarakat dengan berbasis teknlogi modern sehingga menghemat waktu dan biaya anggaran instansi pemerintahan (Nisaurahmadani, 2012). Internet diharapkan bisa mendukung pegawai dalam penyelesaian tugas-tugas yang mereka miliki, dengan demikan pegawai harus mengikuti perkembangan teknologi modern yang ada (Herlianto, 2012). Di sisi lain, dengan adanya teknologi internet, terdapat dampak negatif bagi instansi, yaitu pegawai dapat melalaikan kewajiban dalam melaksanakan tugas instansi. Misalnya, mengakses internet pada waktu jam kerja dengan tujuan bukan untuk kepentingan pekerjaan, tetapi hanya untuk menghilangkan kebosanan di kantor saja. Perilaku inilah yang disebut dengan cyberloafing (Prasetyo, 2011).

Perilaku cyberoafing itu sendiri menurut (Henle dan Blanchard, 2008) terdiri dari serious cyberloafing dan minor cyberloafing. Minor cyberloafing yaitu perilaku cyberloafing untuk penggunaan internet seperti mengirim dan menerima email pribadi, bermain game online, instant messaging dan sebagainya, sedangkan serious cyberloafing adalah penggunaan internet untuk hal yang lebih serius dan berbahaya seperti bermain judi online, ataupun membuka situs terlarang atau pornografi. Dalam penelitian (Lim dan Teo, 2005) menyatakan bahwa beberapa studi di Amerika Serikat menunjukkan 84 persen karyawan berkirim email yang tidak berhubungan dengan pekerjaan dan 90 persen karyawan mengakses internet hanya untuk kesenangan pribadi. Hasil survey ini mengurangi produktivitas sebesar 30-40 persen produktivitas kerja.

Fenomena perilaku cyberloafing tersebut juga terjadi di kantor Pelayanan Bea dan Cukai Kota Pekanbaru. Berdasarkan hasil pengamatan yang dilakukan pada 20 Agustus 2019, diketahui bahwa aktivitas perilaku cyberloafing yang sering dilakukan oleh PNS bea cukai adalah perilaku minor cyberloafing, seperti aktivitas chatting melalui whatsapp, aktivitas bermain media social seperti Instagram, twitter dan facebook. Sedangkan untuk jenis serious cyberloafing tidak ditemukan di kantor ini. Berdasarkan hasil wawancara dengan salah satu pegawai di bidang Penyuluhan Layanan Informasi (PLI) pada 6 April 2020 bahwa situs terlarang seperti pornografi atau judi online telah diblokir di kantor ini, sehingga pegawai tidak dapat menggunakan internet untuk membuka situs terlarang. Salah satu faktor yang dapat mempengaruhi perilaku cyberloafing adalah kontrol diri (Ardilasari \& Firmanto, 2017). Menurut Tangney, Baumeister, dan Boone (2004) kontrol diri didefinisikan sebagai kemampuan diri dalam mengontrol pikiran, emosi, impuls (dorongan) serta melakukan regulasi diri dan mengubah kebiasaan. Menurut Hurlock (2003) mengatakan bahwa kontrol diri berkaitan dengan bagaimana individu mengendalikan emosi serta dorongan-dorongan dalam 
dirinya Gufron \& Risnawita (2011), menjelaskan kontrol diri adalah variabel psikologis sederhana dikarenakan mencakup tiga konsep mengenai kemampuan mengontrol diri yaitu kemampuan individu untuk memodifikasi perilaku, kemampuan individu dalam mengelola informasi yang tidak diinginkan dengan cara menginterpretasi serta kemampuan individu untuk memilih suatu tindakan berdasarkan suatu yang diyakininya. Menurut Tangney, Baumeister, dan Boone (2004) kontrol diri didasari beberapa aspek, yaitu:

\section{Self Dicipline (Disiplin Diri)}

Aspek untuk menilai tentang kedisiplinan pada diri individu dalam melakukan sesuatu misalnya bisa fokus pada tugas. Individu yang memiliki self-discipline mampu menahan diri dari hal- hal lain yang dapat mengganggu konsentrasinya.

Deliberate/Non-impulsive (Tindakan Non Impulsif)

Aspek tentang kecendrungan individu untuk melakukan suatu tindakan yang tidak impulsif. Dimana, individu yang deliberate mempunyai pertimbangan yang baik, bersifat hati- hati dan tidak tergesa-gesa dalam pengambilan keputusan atau bertindak.

\section{Healty Habits (Pola Hidup Sehat)}

Individu dengan kecendrungan healty habits akan mampu menolak sesuatu yang dapat menimbulkan dampak buruk bagi dirinya meskipun hal tersebut hal yang menyenangkan.

Work Ethic (Etika Kerja)

Aspek yang menilai tentang etika seseorang dalam melakukan tugas dan aktivitas sehari-hari. Individu yang memiliki work ethic mampu menyelesaikan tugas tanpa terpengaruh hal-hal yang ada diluar tugasnya

\section{Reliability (Ketahanan)}

Aspek yang menilai kemampuan individu dalam menghadapi sebuah tantangan. Individu dengan reliabilitas mampu melaksanakan perencanaan jangka panjang dalam pencapaian yang ingin diraihnya. Sen, dkk (2016) menyebutkan bahwa perilaku cyberloafing juga dapat disebabkan oleh adanya stres di tempat kerja. Hasil penelitiannya menemukan bahwa ketika stres keja meningkat, maka akan meningkat pula kegiatan menjelajah web untuk kepentingan yang tidak berhubungan dengan pekerjaan. Menurut Robbins (2002) stress kerja dirumuskan dalam tiga aspek, yaitu sebagai berikut:

Aspek Fisologis

Beberapa hal yang menunjukkan gejala fisiologikal yaitu penurunan metabolisme tubuh, detak jantung meningkat dan sesak nafas, naiknya tekanan darah, mudah sakit, dan serangan jantung.

Aspek Psikologis

Hal-hal yang teridentifikasi sebagai gejala psikologikal yaitu merasa tidak puas, merasa tegang, gelisah, mudah marah, cepat bosan, dan suka menunda mengerjakan suatu hal.

Aspek Perilaku 
Perilaku yang mencakup perubahan dalam produktivitas yaitu seperti mudah lupa, perubahan pola makan, menjadi perokok atau mengkonsumsi alkohol, berbicara dengan cepat, perasaan gelisah, serta pola tidur yang tidak teratur.

Perilaku cyberloafing juga disebabkan oleh faktor lain seperti faktor situasional yaitu kedekatan jarak antar ruang pegawai dan atasan (Ardilasari \& Firmanto, 2017). Penelitian Jatipura (2012) di Indonesia khususnya Jabodetabek terhadap 100 pria penderita penyakit jantung menemukan bahwa stres kerja menduduki tempat kedua sebagai penyebab utama penyakit jantung tersebut.

Tuntutan pekerjaan yang dapat menyebabkan pegawai mengalami stres kerja menurut (Benedita, 2018) yaitu pekerjaan di instansi pemerintahan tersebut yang bersifat rutin seperti menyusun surat atau arsip secara cepat dan cermat sehingga untuk mengatasi stres karena tuntutan tersebut pegawai cenderung melakukan perilaku cyberloafing. Sejalan dengan penelitian yang dilakukan (Sen, dkk, 2012) mengemukakan bahwa ketika pegawai mengalami stres kerja maka aktivitas pegawai atau karyawan cenderung untuk menggunakan web pribadi yang tidak berhubungan dengan pekerjaan pun meningkat.Kantor Pelayanan Bea dan Cukai Kota Pekanbaru memiliki pegawai yang berstatus Pegawai Negeri Sipil (PNS). PNS memiliki kewajiban penuh dalam menjalankan visi dan misinya. Kantor Pelayanan Bea dan Cukai Pekanbaru terdiri atas beberapa bagian yang mana dituntut harus dilakukan dengan teliti dan mengikuti prosedur yang ada, terutama untuk bagian pemberantas penyelundupan karena jika salah melakukan tugas atau salah memberikan jumlah berapakah pajak yang harus dibayar maka akan dapat menyebabkan maraknya barang illegal hingga merugikan negara. Tuntutan ini dapat menimbulkan stres kerja, sehingga untuk menanggulangi hal terbut pegawai.

Berdasarkan latar belakang yang telah dijelaskan di atas, maka yang menjadi rumusan masalah masalah dalam penelitian ini adalah apakah terdapat hubungan antara kontrol diri dan stres kerja dengan perilaku cyberloafing pada Pegawai Negeri Sipil (PNS) Di Kantor Pelayanan Bea dan Cukai Kota Pekanbaru?

Hipotesis yang diajukan adalah terdapat hubungan antara kontrol diri dan stress kerja dengan perilaku cyberloafing pada Pegawai Negeri Sipil (PNS) di Kantor Pelayanan Bea dan Cukai Kota Pekanbaru.

\section{Metode}

Penelitian ini menggunakan pendekatan kuantitatif korelasional yang bertujuan mengetahui sejauh mana hubungan antara satu variabel dengan satu atau lebih variabel lainnya berdasarkan koefisien korelasi (Sugiyono, 2013). Populasi dalam penelitian ini merupakan Pegawai Negeri Sipil (PNS) yang bekerja diKantor Pelayanan Bea dan Cukai Kota Pekanbaru yang berjumlah 83 orang. Teknik sampling yang digunakan dalam penelitian ini adalah nonprobability sampling, yaitu dengan teknik sampel jenuh. 
Maka sampel dalam penelitian ini adalah semua Pegawai Negeri Sipil (PNS) Kantor Pelayanan Bea dan Cukai Kota Pekanbaru yang berjumlah 83 orang.

Metode pengumpulan data dalam penelitian ini menggunakan skala yang berbentuk Skala Likert. Adapun skala yang digunakan yaitu skala perilaku cyberloafing yang dimodifikasi dari skala Henita (2019). Skala ini berjumlah 18 aitem. Kemudian skala kontrol diri yang dikembangkan oleh Tangney, Baumeister, dan Boone (2004) yang kemudian dimodifikasi oleh penulis sesuai berjumlah 35 aitem. Selanjutnya skala stres kerja yang merupakan modifikasi dari skala Wildani (2012), berjumlah 30 aitem. Analisis data yang digunakan adalah regresi ganda untuk menganalisa hubungan antara perilaku cyberloafing, kontrol diri dengan stres kerja. Dengan bantuan aplikasi Statistical Product and Service Sollution (SPSS) 20 for Windows.

\section{Hasil}

Berdasrkan data yang diperoleh dari 83 orang sampel, dilakukanlah analisis. Hasil analisis dapat dilihat pada tabel di bawah ini:

Tabel 1. Uji Perbedaan Berdasarkan Usia menggunakan Independent Sample T Test

\begin{tabular}{llccl}
\hline \multicolumn{1}{c}{ Variabel } & \multicolumn{1}{c}{ Kategori Usia } & Mean $(\boldsymbol{\mu})$ & Sig & \multicolumn{1}{c}{ Ket } \\
\hline Perialku & Dewasa Awal (21-40 tahun) & 38,01 & 0,48 & Tidak ada \\
Cyberloafing & Setengah Baya (40-60 tahun) & 33,50 & 5 & perbedaan \\
\multirow{2}{*}{ Kontrol Diri } & Dewasa Awal (21-40 tahun) & 77,56 & 0,00 & Ada \\
& Setengah Baya (40-6- tahun) & 74,50 & 2 & perbedaan \\
\multirow{2}{*}{ Stres Kerja } & Dewasa Awal (21-40 tahun) & 66,02 & 0,54 & Tidak ada \\
& Setengah Baya (40-60 tahun) & 52,50 & 0 & perbedaan \\
\hline
\end{tabular}

Berdasarkan hasil uji independent sample t test, diketahui bahwa tidak terdapat perbedaan perilaku cyberloafing dan stres kerja berdasarkan kategori usia, sementara terdapat perbedaan kontrol diri berdasarkan kategori usia pada Pegawai Negeri Sipil di Kantor Pelayanan Bea dan Cukai Pekanbaru berdasarkan kategori usia. Hal ini bertolak belakang dengan Henle dan Blanchard (2008) bahwa usia dapat mempengaruhi perilaku cyberloafing. Namun hal ini sesuai dengan penelitian Sari dan Ratnaningsih (2018) bahwa usia dapat mempengaruhi kontrol diri. Kemudian untuk stres kerja hal ini bertolak belakang dengan penelitian (Ibrahim, dkk 2016) yang menemukan bahwa karyawan yang berusia dibawah 40 tahun lebih banyak mengalami stres kerja dibanding karyawan yang berusia diatas 40 tahun.

Tabel 2. Hasil uji Korelasi

\begin{tabular}{lccc}
\hline Variabel & $\mathbf{R}$ & Sig & Keterangan \\
\hline Kontrol Diri * Perilaku cyberloafing & $-0,535$ & 0,000 & Ada korelasi \\
Stres Kerja * Perilaku cyberloafing & 0,571 & 0,000 & Ada korelasi \\
Kontrol Diri * Stres Kerja & $-0,599$ & 0,000 & Ada korelasi \\
\hline
\end{tabular}


Berdasarkan hasil analisis korelasi, diperoleh hasil bahwa terdapat korelasi pada ketiga variabel penelitian. Dimana kontrol diri memiliki korelasi negatif terhadap perilaku cyberloafing dengan nilai $\mathrm{r}=-0,535$, sig $=0,000$. Hal ini berarti bahwa semakin tinggi kontrol diri maka semakin rendah perilaku cyberloafing dan semakin rendah konrol diri, maka semakin tinggi perilaku cyberloafing. Hasil yang sama juga terlihat pada variabel kontrol diri dan stress kerja, yaitu terdapat korealasi negatif antara variabel kontrol diri dengan stress kerja dengan nilai $r=-0,599$, sig $=0,000$, artinya bahwa semakin tinggi kontrol diri maka semakin rendah stress kerja dan semakin rendah kontrol diri maka semakin tinggi stress kerja. Sedangkan hasil berbeda diperlihatkan pada korelasi variabel anatara stress kerja dan perilaku cyberloafing yaitu stress kerja memiliki korelasi positif terhadap perilaku cyberloafing dengan nilai $r=$ 0,572 , sig $=0,000$. Hal ini berarti bahwa semakin tinggi stress kerja maka akan semakin tinggi pula perilaku cyberloafing dan semakin rendah stress kerja maka semakin rendah pula perilaku cyberloafing.

Tabel 3. Uji Hipotesis

\begin{tabular}{lcccc}
\hline Variabel & R & R Square & P & Ket \\
\hline $\begin{array}{l}\text { Kontrol diri, Stres kerja dan Perilaku } \\
\text { cyberloafing }\end{array}$ & 0,620 & 0,384 & 0,000 & $\begin{array}{l}\text { Hipotesis } \\
\text { Diterima }\end{array}$ \\
\hline
\end{tabular}

Berdasarkan hasil analisis, diperoleh hasil analisis regresi antara kontrol diri dan stres kerja dengan perilaku cyberloafing pada Pegawai Negeri Sipil di Kantor Pelayanan Bea dan Cukai Pekanbaru dengan nilai koefisien regesi (r) sebesar 0,620 dengan signifikansi 0,000. Hasil penelitian menunjukkan $\mathrm{p}<0,05$ dengan sumbangsih $\mathrm{R}$ Square sebesar $0.384=38,4 \%$ dan sisanya $61,6 \%$ ditentukan oleh faktor lain. Hasil ini menunjukkan adanya hubungan antara kontrol diri dan stres kerja dengan perilaku cyberloafing. Jadi hipotesis yang diajukan dalam penelitian ini diterima yaitu terdapat hubungan antara kontrol diri dan stres kerja dengan perilaku cyberloafing pada Pegawai Negeri Sipil di Kantor Pelayanan Bea dan Cukai Pekanbaru.

Dalam penelitian ini kontrol diri memiliki korelasi negatif dengan perilaku cyberloafing. Sejalan dengan penelitian yang dilakukan oleh (Ardilasari dan Firmanto, 2017) bahwa kontrol diri berpengaruh terhadap perilaku cyberloafing. Selain itu (Sari, 2014) juga mengungkapkan bahwa kontrol diri berkaitan dengan perilaku cyberloafing. Hasil penelitiannya menunjukkan bahwa kontrol diri memberikan pengaruh sebesar $32 \%$ sedangkan sisanya sebesar $68 \%$ dipengaruhi oleh faktor lain. Faktor lain yang dapat mempengaruhi perilaku cyberloafing antara lain faktor sikap dan persepsi yang positif terhadap internet, faktor kebiasaan, sifat seperti rasa malu, kesepian, harga diri, status pekerjaan, tingkat pendidikan dan jenis kelamin (Ozler dan Polat, 2012).

Stres kerja dalam penelitian ini memiliki korelasi positif dengan perilaku cyberloafing. Dimana ketika semakin tinggi stres kerja, maka akan semakin tinggi perilaku cyberloafing yang dilakukan, semakin rendah stres kerja maka akan semakin rendah pula perilaku cyberloafing yang dilakukan. Hasil penelitian ini juga sejalan dengan Sen, dkk (2012) juga mengemukakan bahwa ketika stres kerja meningkat, maka 
perilaku cyberloafing untuk aktivitas penggunaan web pribadi meningkat. Hasil penelitian kategorisasi perilaku cyberloafing pada pegawai berada pada kategorisasi tinggi yaitu 32 orang (38\%) dapat diartikan sebagian besar pegawai melakukan penyimpangan di tempat kerja dalam menggunakan internet untuk kepentingan pribadi, berupa mengunjungi situs hiburan, belanja online, mengakses media sosial, dan aktivitas menjelajah internet lainnya. Hal ini sesuai dengan yang diungkapkan oleh Henle \& Blanchard (2008) yang menyatakan bahwa cyberloafing adalah perilaku pegawai yang menggunakan akses internet dengan jenis desktop, cell-phone, tablet saat bekerja untuk aktivitas non-destruktif dimana hal tersebut tidak berhubungan dengan pekerjaan seperti hiburan, belanja online, internet messaging, dan aktivitas menjelejah web lainnya. Kontrol diri pada Pegawai pada penelitian ini berada pada kategorisasi sedang yaitu 27 orang (32\%) dapat diartikan setengah subjek memiliki kontrol diri dalam tingkat sedang. Artinya pegawai cukup memiliki kontrol diri yang baik sehingga dapat mengendalikan diri dalam kehidupan terutama saat bekerja untuk mengendalikan emosi serta dorongan-dorongan dalam dirinya yang bertentangan dengan norma yang ada. Sesuai dengan yang dikatakan oleh Hurlock (1990) mengatakan bahwa kontrol diri berkaitan dengan bagaimana individu mengendalikan emosi serta dorongan-dorongan dalam dirinya.

Stres kerja pada pegawai berada pada kategorisasi sedang yaitu 38 orang (46\%) dapat diartikan hampir setengah Pegawai Negeri Sipil di Kantor Pelayanan Bea Dan Cukai Kota Pekanbaru memiliki stres kerja sedang. Artinya subjek dalam penelitian ini cukup merasakan ketegangan di tempat kerja karena tekanan yang bersumber dari dirinya ataupun dari luar dirinya. Pegawai Negeri Sipil Di Kantor Pelayanan Bea dan Cukai Kota Pekanbaru cenderung mengalami gejala-gejala stres kerja seperti sering sakit kepala saat banyak pekerjaan, merasa lelah pada bagian otot leher dan bahu, tidur tidak teratur, meningkatnya penggunaan rokok, dan lainnya.

Berdasarkan hasil koefisien determinasi dapat diketahui bahwa kontrol diri dan stres kerja memiliki kontribusi sebesar $38,4 \%$ terhadap perilaku cyberloafing. Hal ini dibuktikan melalui nilai r-squared sebesar 38,4\%, artinya kontribusi variabel kontrol diri dan stres kerja terhadap perilaku cyberloafing sebesar 38,4\%, sedangkan $61,6 \%$ dipengaruhi oleh faktor lain. Nilai sumbangan efektif dalam penelitian ini tergolong rendah, karena ada variabel moderator lain yang mempengaruhi. Faktor lain yang mempengaruhi perilaku cyberloafing menurut Said (2013) yaitu dapat dipengaruhi oleh lingkungan kerja yang baik sehingga dapat mengurangi perilaku atau respon kerja yang negatif. Hasil penelitian (Liberman, dkk, 2011) membuktikan bahwa lingkungan kerja yang mendukung bagi karyawan dapat menghindari perilaku negatif seperti perilaku cyberloafing. Oleh karena itu dapat disimpulkan bahwa variabel kontrol diri dan stres kerja tidak sepenuhnya menjadi faktor yang dapat mempengaruhi perilaku cyberloafing pada pegawai negeri sipil.

\section{Kesimpulan}


Berdasarkan hasil penelitian diperoleh bahwa terdapat hubungan antara kontrol diri dan stres kerja dengan perilaku cyberloafing pada Pegawai Negeri Sipil di Kantor Pelayanan Bea dan Cukai Kota Pekanbaru. Hal ini menunjukkan bahwa terdapat hubungan negatif antara kontrol diri dengan perilaku cyberloafing dan terdapat hubungan positif antara stres kerja dengan perilaku cyberloafing. Artinya semakin tinggi kontrol diri maka akan semakin rendah perilaku cyberloafing yang dilakukan, sebaliknya semakin rendah kontrol diri maka akan semakin tinggi perilaku cyberloafing yang dilakukan. Sedangkan untuk stres kerja, jika semakin tinggi stres kerja maka akan semakin tinggi perilaku cyberloafing yang dilakukan, sebaliknya jika semakin rendah stres kerja seseorang maka akan semakin rendah pula perilaku cyberloafing yang dilakukan.

\section{Saran}

Berdasarkan hasil penelitian yang diperoleh, berikut beberapa saran untuk pihakpihak terkait dalam penelitian ini yaitu sebagai berikut:

Bagi Pegawai Negeri Sipil di Kantor Bea Cukai Pekanbaru

Bagi Pegawai Negeri Sipil di Kantor Bea Cukai Provinsi Riau, dengan adanya penelitian ini diharapkan pegawai dapat meningkatkan kontrol diri dengan cara disiplin diri, fokus pada tujuan, serta tidak tergesa-gesa dalam menngambil keputusan agar pegawai terhindar dari adanya stres kerja dan terjadinya perilau cyberloafing

Bagi Instansi

Bagi Instansi Pemerintahan, karena kategorisasi stres kerja dan perilaku cyberloafing pegawai cukup tinggi, instansi sebaiknya dapat membuat kriteria dan kejelasan cyberloafing apa yang dilarang, sehingga dapat diterapkan sanksi yang tepat. Kemudian perlu lebih selektif dalam menentukan tugas bagi pegawai dan disesuaikan dengan kemampuan agar terhindar dari stres kerja, yang mana akan membuat pegawai cenderung melakukan perilaku cyberloafing.

Bagi Peneliti Selanjutnya

Untuk dapat melanjutkan penelitian ini dengan melakukan penggalian informasi awal yang lebih mendalam mengenai perilaku cyberloafing. Selain itu, melakukan perbaikan dalam modifikasi aitem untuk memilimalisir terjadinya social desirability. Serta, bagi peneliti selanjutnya yang ingin melakukan penelitian dengan judul yang sama, dapat menjadikan penelitian ini menjadi salah satu referensi peneltian terkait perilaku cyberloafing.

\section{Referensi}

Aghaz, A \& Sheikh. A. (2016). Cyberloafing and job burnout: An investigation in the knowledge- intensive sector. Journal. Computers In Human Behavior, 62, 51-60

Ardilasari dan Firmanto. 2017. Hubungan Self Control Dengan Perilaku Cyberloafing Pada Pegawai Negeri Sipil. Jurnal Ilmiah Psikologi Terapan. Vol.5 No.1 
Arikunto, S. (2008). Prosedur Penelitian Suatu Pendekatan Praktik. Jakarta: Rineka Karya.

Benedita, R. (2018). Pengaruh beban kerja, peran ganda, dan lingkungan kerja terhadap perilaku cyberloafing pegawai (Studi Kasus Pada Dinas Pendidikan dan Kebudayaan Kota Tangerang Selatan). Skripsi.

Dhania, Dhini Rama. (2010). Pengaruh Stres Kerja, Beban Kerja Terhadap Kepuasan Kerja (Studi pada Medical Representatif di Kota Kudus). Jurnal Psikologi Universitas Muria Kudus, Volume 1, Nomor 1.

Ghufron, M. Nur \& Rini Risnawita S. 2011. Teori-Teori Psikologi. Ar-Ruzz media. Jogjakarta

Henle A. Christine dan Blanchard L., Blanchard. (2008), The Interaction of Work Stressors and Organizational Sanctions on Cyberloafing Journal Of Managerial Issue, Vol. XX Number 3 fall 2008: 383- 400.

Herdiati, dkk (2015). Pengaruh Stresor Kerja dan Persepsi Sanksi Organisasi terhadap Perilaku Cyberloafing di Universitas Jember. Jurnal Pustaka Kesehatan, vol. 3 no.1.

Herlianto, A.W. (2012). Pengaruh Stres Kerja Pada Cyberloafing. Jurnal Ilmiah Mahasiswa Manajemen, Vol 1, No 2. Universitas Katolik Widya Mandala. Surabaya

Hurlock, E. B. (2003). Psikologi Perkembangan: Suatu Pendekatan Sepanjang Rentang Kehidupan. Alih Bahasa: Soedjarwo dan Iswidayanti. Jakarta: Erlangga.

Ibrahim, dkk. (2016). Faktor-Faktor yang Berhubungan Dengan Stres Kerja Pada Pekerja Factory 2 PT. Maruki Internasional Indonesia Makassar. Al - Sihah : Public Health Science Journal

Liberman, dkk. (2011). Employee job attitudes and organizational characteristics as predictorsof cyberloafing. Journal Homepage: Computer in Human Behavior. 27 (2011).

Lim, V. K. G., \& Teo, T. S. H. (2005). Prevalence, perceived seriousness, justification, and regulation of cyberloafing in Singapore: An exploratory study. Journal of Information and Management.

Nisaurrahmadani, S.H. (2012). Hubungan Stres Kerja Dengan Perilaku CyberloafingPada Karyawan Administrasi. Universitas Muhammadiyah Malang. Skripsi.

Ozler, D. E., \& Polat, G. (2012). Cyberloafing phenomenon in organizations: Determinants and impacts. International Journal of $e$ - Bussiness and eGovernment Studies, 4(2), 1-15

Robbins, Stephen P. 2002. Organizational Behavior, Alih Bahasa Dr. Handayani Pujoatmoko, Jakarta; PT. Prenhaltindo 
Hubungan Antara Kontrol Diri Dan Stres Kerja Dengan Perilaku Cyberloafing Pada Pegawai Negeri Sipil (PNS) Di Kantor Pelayanan Bea Dan Cukai Kota Pekanbaru

Said, A. I., Shamsudin, F. M., \& Subramaniam, C. (2013). Do Human Resource Management Practices Matter In Reducing Cyberloafing At Work: Evidence From Jordan. Journal of WEI Business and Economics, Vol.02, No. 02.

Sari \& Ratnaningsih. (2018). Hubungan Antara Kontrol Diri Dengan Intensi Cyberloafing Pada Pegawai Dinas X Provinsi Jawa Tengah. Jurnal Empati: Vol. 07, No. 02.

Sen, dkk. (2016). The Effects Of Work Stress On Cyberloafing Behavior In Higher Education Institutions. Volume:S1: 523-535. Jurnal.

Sugiyono. (2017). Metode Penelitian Pendekatan Kuantitatif, dan $R \&$ D. Bandung : Alfabeta

Tangney, J.P., Baumeister, R.F., \& Boone, A.L. (2004). High Self-control Predicts Good Adjustment, Less Pathology, Better Grades, and Interpersonal Success. Journal of Personality, 5, (2).

Wildani, A.M. (2012). Gambaran Tingkat Stres Kerja pada Pegawai Dias Kesehatan Kota Depok. Universitas Indonesia. Depok. Skripsi 